\title{
Epidemiological survey of oil distribution centres in Britain
}

\author{
L RUSHTON AND M R ALDERSON \\ From the Division of Epidemiology, Institute of Cancer Research, Sutton, Surrey SM2 5PX, UK
}

ABSTRACT A mortality study of workers employed for at least one year between 1 January 1950 and 31 December 1975 at oil distribution centres from three oil companies in Britain has been carried out. Ninety nine per cent of the population were successfully traced to determine their vital status at 31 December 1975 . The mortality observed in the study population was compared with that which would be expected from the mortality rates for all the male population of England and Wales. The overall mortality observed was considerably lower than expected on this basis as was the mortality from stroke, hypertensive disease, bronchitis, and pneumonia. The observed number of deaths from all neoplasms was also much less than expected as were the observed deaths from lung cancer. The observed deaths from ischaemic heart disease approximately equalled those expected overall and in each of the companies, however, and there was no evidence of a "healthy worker effect" for this disease group. The ratio of observed over expected deaths from ischaemic heart disease tended to decrease with increasing age at death, and for most of the job groups overall, the observed and expected deaths were about the same. Raised mortality patterns from ischaemic heart disease were found in several subgroups of the population of one company. Mortality from myelofibrosis and diseases of the lymphatic and haematopoietic tissue was slightly raised overall. Only myelofibrosis showed an overall excess but raised mortality was found in subgroups of the population defined by company, job, and length of service in several of the other neoplasms making up this disease group. The numbers of deaths from these causes were all small, making it difficult to exclude chance effects. Further work would be required to ascertain whether these results are due to an occupational factor and if so to identify the physical or chemical nature of the risk.

The present study is the third part of a wider study of workers in the oil industry which has been carried out by the same research team. A similar mortality study of workers in oil refineries ${ }^{1}$ and a case control study to investigate the possible association between exposure to benzene and death from leukaemia in refinery workers have been carried out. ${ }^{2}$ Many aspects of the design, method, and analyses of the distribution centre study are similar to those used in the oil refinery study. ${ }^{1}$ A study of maintenance men at London Transport bus garages and Chiswick Works has also been carried out. ${ }^{3}$

\section{Previous studies on the hazards associated with oil}

Many papers have described the carcinogenic effects of exposure to mineral oil, both to animals ${ }^{45}$ and

Received 2 June 1982

Accepted 25 August 1982 people in various occupations. ${ }^{67}$ In the petroleum industry specific issues investigated include the health of asphalt workers, ${ }^{8}$ the occurrence of skin cancer, and cancer of the scrotum in wax pressmen. ${ }^{910}$ Several mortality studies have also been carried out on oil refinery workers. ${ }^{11-13}$ There have been relatively few studies of workers in oil distribution centres although they have been included in wider studies of the oil industry or studies of populations defined by their proximity to the petroleum industry. ${ }^{14-16}$ Several studies have measured $(a)$ the intake of benzene vapour, a constituent of petrol, using personal air sampling and $(b)$ the metabolism of benzene evaluated from the concentration of phenol in urine for workers at bulk marketing terminals and for petrol pump attendants at garages. ${ }^{17-20}$ A study of marine terminals describes the source of hydrocarbon emissions and discusses the problem of safety involved in the application of control technology. ${ }^{21}$ 
Measurement of hydrocarbon vapour concentrations in the employees' breathing zone using various loading and control systems for gasoline tank trucks was carried out. ${ }^{22}$ It was concluded that gasoline exposure to driver salesmen and to loaders at loading racks did not pose a health hazard. The importance of controlling any leaks, spills, and improper loading procedures that might contribute to employees' exposure was emphasised.

A survey of the nature and duration of mineral oil exposure at selected oil distribution terminals in one United Kingdom company was carried out (E King, unpublished data, 1969). The cleanliness of the plants and the men operating them and the potential areas of oil exposure were described for the various processes in each terminal. The washing facilities, provision of protective clothing, and display of warning notices at each terminal were also discussed.

\section{Method}

The present study included all men with a length of service of at least one continuous year between 1 January 1950 and 31 December 1975 at distribution centres in Britain. The distribution centres include airports and blending plants. Three companies (A, $B$, and $C$ ) provided the data.

The following data were collected from personnel and pension departments at the company head and regional offices: for all men full name, date of birth, address, distribution centre, date of joining, and last or present job; for leavers, date of leaving, reason for leaving (retired, died, or other), and National Insurance (NI) number if available.

A feasibility study had considered collecting a detailed job history for each man but this would have been a lengthy and costly task. The availability of job history information was also inconsistent between companies. It was therefore decided to use last job title. As many different job titles were used by the companies these were coded to 11 broader job groups (table 1). For the analyses the following

Table 1 Distribution of job classification of study population (not including untraced men)

\begin{tabular}{lrr}
\hline & No & $(\%)$ \\
\hline Operators & 4660 & $(20)$ \\
Greasemakers & 44 & $(0)$ \\
Drivers & 10108 & $(43)$ \\
Craftsmen & 796 & $(4)$ \\
Motor mechanics & 582 & 3 \\
Scientists/technicians & 217 & 1 \\
General manual workers & 1612 & 7 \\
Security men & 467 & 2 \\
Supervisors & 1686 & $(7)$ \\
Administrators/clerical workers & 2369 & $(10)$ \\
Managers & 765 & $(3)$ \\
$\quad$ Total & 23306 & $(100)$ \\
\hline
\end{tabular}

groups have been combined to provide large enough numbers: operators and greasemakers; craftsmen, motor mechanics, scientists, and technicians; and administrators, clerical workers, and managers. These are referred to as operators, craftsmen, and administrators respectively.

Information, including dates of death, was available on pensioners from some companies. All other leavers, where contact with the company had been lost, were traced either through the Social Security records at Newcastle or through the National Health Service Central Registers (NHSCR) at Southport and Edinburgh. Full details of death were obtained for all men found to be dead either directly from the NHSCRS or from the Office of Population Censuses and Surveys.

As there were no National Health Service numbers available from the companies and some records did include the National Insurance number all tracing was done through the Social Security records first and the NHSCRs were then used if this first attempt was unsuccessful.

The causes of death, both underlying cause and up to three contributory causes, were coded using the appropriate revision of the International Classification of Diseases. ${ }^{23}$ In the analysis the underlying cause was used in comparing observed with expected deaths. The contributory causes were used to identify other cases where the disease of interest was an associated cause rather than the actual cause of death.

The number of years each man was in the study (person years) was calculated from his date of birth and dates of entry to and exit from the study using the man years computer language program. ${ }^{24}$ The total person years were subdivided into five year age and calendar period groups. As all men in the study had a minimum of one year's service between 1 January 1950 and 31 December 1975 date of entry to the study was (a) 1 January 1951 for men who joined before 1950 and $(b)$ one year after joining for those who joined after 1 January 1950 .

The expected deaths were calculated by applying the five year age and calendar period death rates of the comparison population to the five year age and calendar period person years of the study population to obtain age and calendar period expected deaths which were summed to give the total expected deaths.

The comparison population used in the distribution centre study was the population of men in England and Wales. In the refinery study ${ }^{1}$ the expected deaths for the two Scottish refineries were calculated using Scottish rates. A correction was also made for geographical variation in mortality for the England and Welsh refineries using a simple method based 
on the three standard regions in which the refineries were sited. It was decided not to do this for the distribution centre study as separating the data into Scotland and ten standard regions in England and Wales would have reduced the numbers too much for analysis. Nevertheless, the geographical position of particular centres has been taken into account in the interpretation of the results.

In addition to differences in mortality between areas some diseases show well defined gradients of mortality across the social classes. The interpretation of the results from adjustment of expected deaths for social class variation and the limited mortality data available by social class for a detailed list of cause of death has been discussed. ${ }^{1}$ In the present study social class adjustment has not been carried out. When interpreting the results for the various job groups used in this study, due consideration has been given to known social class variation and an attempt made to judge whether the difference between observed and expected deaths is likely to reflect non-occupational factors.

The grouping of the causes of death was determined by that of the available comparison data. For 30 malignant causes the groups were those used in the serial mortality tables. ${ }^{25}$ For the non-malignant causes, data for the A list of 150 causes of death from the 7th revision of the International Classification of Diseases were made available by the World Health Organisation.

The difference between the observed and expected deaths was examined by calculating a significance level ( $p$ value) for the observed number of deaths assuming it to be drawn from a Poisson distribution with mean equal to the externally calculated expected value.

As in the previous refinery study ${ }^{1}$ two approaches to the analysis were used. Firstly, a search for pronounced excesses and deficits in numbers of observed deaths compared with those expected was made. An examination of the data by company, age, job, year of entry, length of service, and reason for leaving was then carried out to describe and estimate the patterns of mortality more fully. Since, in this approach, hypotheses were not being formally tested, the significance levels obtained in these analyses have been used informally as guidelines to indicate the magnitude and direction of the variations in mortality. The second approach involved a priori testing of the findings from previous studies discussed in the introduction.

\section{Results}

Table 2 gives the status of the study population at the study end date, 31 December 1975 . Only $0 \cdot 2 \%$
Table 2 Status of study population at study end date 31 December 1975

\begin{tabular}{lrr}
\hline & No & $(\%)$ \\
\hline In employment & 8470 & $(36 \cdot 3)$ \\
Left employment & & \\
Alive & 10904 & $(46 \cdot 7)$ \\
Dead, cause known & 3903 & $(16 \cdot 7)$ \\
Dead, cause unknown & 23 & $(0 \cdot 1)$ \\
Emigrated & 6 & $(0 \cdot 0)$ \\
Untraced & 52 & $(0 \cdot 2)$ \\
$\quad$ Total & 23358 & $(100 \cdot 0)$ \\
\hline
\end{tabular}

of the men were untraced and these have not been included in the analysis. There was a total of 397569 person years of observation with a mean follow up of $17 \cdot 1$ years for each man.

\section{NON-MALIGNANT CAUSES OF DEATH}

The total number of non-malignant deaths was significantly lower than expected (table 3 ), a deficit that is also reflected in some of the circulatory disease groups including chronic rheumatic heart disease, other diseases of the heart, and hypertensive disease. The same is true for diseases of the respiratory system, especially tuberculosis, influenza, pneumonia, and bronchitis.

In general the pattern of lowered mortality from these disease groups was found across all subgroups (defined, for example, by job, age, and length of service). There were three excesses overall for general manual workers: cerebrovascular disease $(\mathrm{O}=52$, $E=36.98, p<0.01)$; other diseases of the circulatory system $(O=6, E=2.90, p=0.07)$; and asthma $(\mathrm{O}=4, \mathrm{E}=0.76, \mathrm{p}<0.01)$. There was also an excess from bronchitis for security men $(\mathrm{O}=37, \mathrm{E}$ $=25.56, \mathrm{p}<0.05)$.

There were slightly more deaths overall from motor vehicle accidents, especially in company $\mathrm{B}(\mathrm{O}$ $=57 / 45.50, p=0.06)$. Just under half the deaths in this company were men who left for "other reasons" $(\mathrm{O}=27, \mathrm{E}=13.29, \mathrm{p}<0.01)$, often after less than five years' service. Many of the motor vehicle accidents were in fact motor cycle accidents.

There were seven deaths from accidental fire and explosion $(\mathrm{O}=7, \mathrm{E}=\mathbf{4} \cdot 2, \mathrm{p}=0 \cdot 13)$ but only five of these were due to accidents at work.

\section{Ischaemic heart disease}

There were approximately the same number of deaths observed (1377) from ischaemic heart disease as expected (1384). In most occupational mortality studies of this type, where the national population is used for comparison, a significant deficit would be expected from this disease. More detailed results for this disease group are thus now presented.

Table 4 gives the observed (O) and expected (E) deaths, $\mathrm{O} / \mathrm{E}$, and $\mathrm{p}$ values by age, job, year of entry, 
Table 3 Observed and expected deaths $(O / E)$ and $p$ values for all causes and non-malignant causes with 10 ar more observed deaths for workers employed in oil distribution centres in Britain from 1 January 1950 to 31 December 1975

\begin{tabular}{|c|c|c|c|c|}
\hline Causes (in ICD order) & Observed deaths & Expected deaths & $O / E$ & $p$ \\
\hline $\begin{array}{l}\text { All causes } \\
\text { Tuberculosis of respiratory system } \\
\text { Diabetes } \\
\text { Cerebrovascular disease } \\
\text { Chronic rheumatic heart disease } \\
\text { Ischaemic heart disease } \\
\text { Other diseases of heart } \\
\text { Hypertensive disease } \\
\text { Diseases of arteries } \\
\text { Other diseases circulatory system } \\
\text { Influenza } \\
\text { Pneumonia } \\
\text { Bronchitis } \\
\text { Asthma } \\
\text { Peptic ulcer } \\
\text { Chronic and other nephritis } \\
\text { Infections of the kidney } \\
\text { Hyperplasia of prostate } \\
\text { Other diseases genitourinary system } \\
\text { Motor vehicle accidents } \\
\text { Accidental falls } \\
\text { Suicide }\end{array}$ & $\begin{array}{r}3926 \\
11 \\
19 \\
374 \\
31 \\
1377 \\
71 \\
65 \\
81 \\
36 \\
13 \\
133 \\
240 \\
15 \\
40 \\
15 \\
11 \\
10 \\
10 \\
75 \\
17 \\
38\end{array}$ & $\begin{array}{r}4632 \cdot 13 \\
49 \cdot 19 \\
26 \cdot 49 \\
430 \cdot 70 \\
59 \cdot 37 \\
1384 \cdot 24 \\
110.70 \\
91 \cdot 93 \\
88 \cdot 86 \\
35 \cdot 94 \\
26 \cdot 12 \\
185 \cdot 28 \\
358 \cdot 63 \\
15 \cdot 18 \\
50.73 \\
32 \cdot 27 \\
12 \cdot 63 \\
16 \cdot 38 \\
7 \cdot 70 \\
69.92 \\
24 \cdot 36 \\
67 \cdot 06\end{array}$ & $\begin{array}{l}0.85 \\
0.22 \\
0.72 \\
0.87 \\
0.52 \\
0.99 \\
0.64 \\
0.71 \\
0.91 \\
1.00 \\
0.50 \\
0.72 \\
0.67 \\
0.99 \\
0.79 \\
0.46 \\
0.87 \\
0.61 \\
1.30 \\
1.07 \\
0.70 \\
0.57\end{array}$ & $\begin{array}{l}<0.0001 \\
<0.0001 \\
0.08 \\
0.01 \\
<0.0001 \\
0.84 \\
<0.001 \\
<0.01 \\
0.22 \\
0.52 \\
<0.01 \\
<0.0001 \\
<0.0001 \\
0.55 \\
0.07 \\
<0.001 \\
0.39 \\
0.07 \\
0.25 \\
0.29 \\
0.08 \\
<0.0001\end{array}$ \\
\hline
\end{tabular}

Table 4 Observed deaths $(O)$, expected deaths $(E), O / E$, and $p$ values for ischaemic heart disease by company, age, job, year of entry, and length of service*

\begin{tabular}{|c|c|c|c|c|c|c|c|c|c|c|c|c|c|c|c|c|}
\hline & \multicolumn{4}{|c|}{ Company $A$} & \multicolumn{4}{|c|}{ Company $B$} & \multicolumn{4}{|c|}{ Company $C$} & \multicolumn{4}{|c|}{ Total } \\
\hline & $O$ & $E$ & $O / E$ & $p$ & $O$ & $E$ & $O / E$ & $p$ & $O$ & $E$ & $O / E$ & $p$ & $O$ & $\boldsymbol{E}$ & $O / E$ & $p$ \\
\hline $\begin{array}{l}\text { Total population } \\
\text { Age: }\end{array}$ & 78 & $83 \cdot 19$ & 0.94 & 0.31 & 834 & $832 \cdot 19$ & 1.00 & 0.95 & 465 & $468 \cdot 86$ & 0.99 & 0.84 & 1377 & $1384 \cdot 24$ & 0.99 & 0.84 \\
\hline $\begin{array}{l}<45 \\
45-54 \\
55-64 \\
65-74 \\
\quad \geqslant 75\end{array}$ & $\begin{array}{r}5 \\
24 \\
23 \\
17 \\
9\end{array}$ & $\begin{array}{r}5 \cdot 97 \\
18 \cdot 25 \\
27.93 \\
23.40 \\
7 \cdot 63\end{array}$ & $\begin{array}{l}0.84 \\
1 \cdot 32 \\
0.82 \\
0.73 \\
1 \cdot 18\end{array}$ & $\begin{array}{l}0.45 \\
0.11 \\
0.20 \\
0.11 \\
0.36\end{array}$ & $\begin{array}{r}58 \\
188 \\
259 \\
265 \\
64\end{array}$ & $\begin{array}{r}48 \cdot 00 \\
154 \cdot 30 \\
269 \cdot 41 \\
269 \cdot 71 \\
90.76\end{array}$ & $\begin{array}{l}1 \cdot 21 \\
1 \cdot 22 \\
0.96 \\
0.98 \\
0.71\end{array}$ & $\begin{array}{l}0.09 \\
0.007 \\
0.50 \\
0.77 \\
0.002\end{array}$ & $\begin{array}{r}14 \\
64 \\
148 \\
189 \\
50\end{array}$ & $\begin{array}{r}15.20 \\
61.43 \\
152.99 \\
182 \cdot 14 \\
57.09\end{array}$ & $\begin{array}{l}0.92 \\
1.04 \\
0.97 \\
1.04 \\
0.88\end{array}$ & $\begin{array}{l}0.45 \\
0.39 \\
0.67 \\
0.60 \\
0.19\end{array}$ & $\begin{array}{l}77 \\
276 \\
430 \\
471 \\
123\end{array}$ & $\begin{array}{r}69.17 \\
233.98 \\
450.33 \\
475.25 \\
155.48\end{array}$ & $\begin{array}{l}1.11 \\
1.18 \\
0.95 \\
0.99 \\
0.79\end{array}$ & $\begin{array}{l}0.19 \\
0.001 \\
0.33 \\
0.84 \\
0.00 !\end{array}$ \\
\hline \multicolumn{17}{|l|}{ Job: } \\
\hline $\begin{array}{l}\text { Operator } \\
\text { Driver } \\
\text { Craftsman } \\
\text { General manual }\end{array}$ & $\begin{array}{r}6 \\
34 \\
10\end{array}$ & $\begin{array}{r}8 \cdot 52 \\
30 \cdot 56 \\
5 \cdot 17\end{array}$ & $\begin{array}{l}0.70 \\
1 \cdot 11 \\
1 \cdot 93\end{array}$ & $\begin{array}{l}0.25 \\
0.29 \\
0.04\end{array}$ & $\begin{array}{r}170 \\
305 \\
40\end{array}$ & $\begin{array}{r}162 \cdot 01 \\
307 \cdot 56 \\
44 \cdot 35\end{array}$ & $\begin{array}{l}1.05 \\
0.99 \\
0.90\end{array}$ & $\begin{array}{l}0.53 \\
0.59 \\
0.29\end{array}$ & $\begin{array}{r}115 \\
154 \\
38\end{array}$ & $\begin{array}{r}107 \cdot 23 \\
157 \cdot 54 \\
43 \cdot 67\end{array}$ & $\begin{array}{l}1 \cdot 07 \\
0.98 \\
0.87\end{array}$ & $\begin{array}{l}0.45 \\
0 \cdot 37 \\
0 \cdot 22\end{array}$ & $\begin{array}{r}291 \\
493 \\
88\end{array}$ & $\begin{array}{r}277 \cdot 76 \\
495.66 \\
93.19\end{array}$ & $\begin{array}{l}1.05 \\
0.99 \\
0.94\end{array}$ & $\begin{array}{l}0.42 \\
0.66 \\
0.32\end{array}$ \\
\hline $\begin{array}{l}\text { worker } \\
\text { Security man } \\
\text { Administrator } \\
\text { Supervisor }\end{array}$ & $\begin{array}{l}8 \\
7 \\
7 \\
6\end{array}$ & $\begin{array}{r}14 \cdot 95 \\
8 \cdot 33 \\
9 \cdot 68 \\
5 \cdot 98\end{array}$ & $\begin{array}{l}0.54 \\
0.84 \\
0.72 \\
1 \cdot 00\end{array}$ & $\begin{array}{l}0.04 \\
0.41 \\
0.25 \\
0.55\end{array}$ & $\begin{array}{r}70 \\
49 \\
121 \\
79\end{array}$ & $\begin{array}{r}64 \cdot 86 \\
58 \cdot 93 \\
106 \cdot 20 \\
88 \cdot 19\end{array}$ & $\begin{array}{l}1 \cdot 08 \\
0.83 \\
1 \cdot 14 \\
0.90\end{array}$ & $\begin{array}{l}0.28 \\
0.11 \\
0.15 \\
0.18\end{array}$ & $\begin{array}{r}40 \\
9 \\
56 \\
53\end{array}$ & $\begin{array}{l}30.58 \\
15.52 \\
53.25 \\
61.07\end{array}$ & $\begin{array}{l}1.31 \\
0.58 \\
1.05 \\
0.87\end{array}$ & $\begin{array}{l}0.06 \\
0.05 \\
0.37 \\
0.17\end{array}$ & $\begin{array}{r}118 \\
65 \\
184 \\
138\end{array}$ & $\begin{array}{c}110.39 \\
82.78 \\
169 \cdot 22 \\
155.24\end{array}$ & $\begin{array}{l}1.07 \\
0.79 \\
1.09 \\
0.89\end{array}$ & $\begin{array}{l}0.46 \\
0.03 \\
0.26 \\
0.16\end{array}$ \\
\hline $\begin{array}{l}\text { Year of entry: } \\
\text { Pre-1940 } \\
1940-9 \\
1950-9 \\
\geqslant 1960\end{array}$ & $\begin{array}{r}12 \\
20 \\
42 \\
4\end{array}$ & $\begin{array}{r}13 \cdot 56 \\
21 \cdot 20 \\
39 \cdot 28 \\
9 \cdot 15\end{array}$ & $\begin{array}{l}0.88 \\
0.94 \\
1.07 \\
0.44\end{array}$ & $\begin{array}{l}0.40 \\
0.45 \\
0.35 \\
0.05\end{array}$ & $\begin{array}{r}446 \\
186 \\
147 \\
55\end{array}$ & $\begin{array}{r}445.43 \\
194.50 \\
142.40 \\
39.86\end{array}$ & $\begin{array}{l}0.98 \\
0.96 \\
1.03 \\
1.38\end{array}$ & $\begin{array}{l}0.20 \\
0.53 \\
0.67 \\
0.01\end{array}$ & $\begin{array}{r}384 \\
34 \\
32 \\
15\end{array}$ & $\begin{array}{r}380.77 \\
37 \cdot 24 \\
35.55 \\
15.31\end{array}$ & $\begin{array}{l}1.01 \\
0.91 \\
0.90 \\
0.98\end{array}$ & $\begin{array}{l}0.86 \\
0.33 \\
0.31 \\
0.54\end{array}$ & $\begin{array}{r}842 \\
240 \\
221 \\
73\end{array}$ & $\begin{array}{r}849 \cdot 76 \\
252 \cdot 94 \\
217 \cdot 23 \\
64 \cdot 32\end{array}$ & $\begin{array}{l}0.99 \\
0.95 \\
1.02 \\
1.15\end{array}$ & $\begin{array}{l}0.78 \\
0.41 \\
0.79 \\
0.13\end{array}$ \\
\hline \multicolumn{17}{|l|}{$\begin{array}{l}\text { Length of service } \\
\text { (years): }\end{array}$} \\
\hline $\begin{array}{l}0-4 \\
5-9 \\
10-14 \\
15-19 \\
\geqslant 20\end{array}$ & $\begin{array}{l}23 \\
15 \\
14 \\
14 \\
12\end{array}$ & $\begin{array}{r}24 \cdot 40 \\
18 \cdot 18 \\
15 \cdot 32 \\
8 \cdot 92 \\
16 \cdot 36\end{array}$ & $\begin{array}{l}0.94 \\
0.83 \\
0.91 \\
1.57 \\
0.73\end{array}$ & $\begin{array}{l}0 \cdot 44 \\
0 \cdot 27 \\
0 \cdot 43 \\
0 \cdot 07 \\
0 \cdot 17\end{array}$ & $\begin{array}{r}75 \\
89 \\
105 \\
114 \\
451\end{array}$ & $\begin{array}{r}73.15 \\
103.00 \\
94.16 \\
93.09 \\
468.77\end{array}$ & $\begin{array}{l}1.03 \\
0.86 \\
1.12 \\
1.22 \\
0.96\end{array}$ & $\begin{array}{l}0.43 \\
0.17 \\
0.14 \\
0.02 \\
0.41\end{array}$ & $\begin{array}{r}4 \\
15 \\
19 \\
30 \\
397\end{array}$ & $\begin{array}{r}7.45 \\
13.78 \\
22.55 \\
37.28 \\
387.82\end{array}$ & $\begin{array}{l}0.54 \\
1.09 \\
0.84 \\
0.80 \\
1.02\end{array}$ & $\begin{array}{l}0.14 \\
0.41 \\
0.27 \\
0.13 \\
0.65\end{array}$ & $\begin{array}{l}102 \\
119 \\
138 \\
158 \\
860\end{array}$ & $\begin{array}{l}105.00 \\
134.96 \\
132.03 \\
139.29 \\
872.95\end{array}$ & $\begin{array}{l}0.97 \\
0.88 \\
1.05 \\
1.13 \\
0.99\end{array}$ & $\begin{array}{l}0.93 \\
0.17 \\
0.59 \\
0.11 \\
0.66\end{array}$ \\
\hline
\end{tabular}

*Results for the 1377 deaths are repeated for each of the classifying variables of age, job, year of entry, and length of service.

and length of service for each company and the total population. The ratio of observed over expected deaths tended to decrease with increasing age at death. A slight excess was found in company B for deaths aged under 45 and pronounced excesses for men aged 45-54 at death for company B and over- all. There was a pronounced deficit for men aged 75 or over at death from company B and overall.

For most of the job groups the observed and expected deaths were approximately the same. There was a deficit overall for security men and from company C. There was a slight excess for general 
manual workers from company $\mathrm{C}$ but a deficit for general manual workers from company A. An excess was found for craftsmen from company $A$. The ratio of observed over expected deaths tended to increase with later cohort of entry with a pronounced excess at company B for those joining in 1960 or after. The ratio of observed over expected deaths also tended to increase with increasing length of service with an excess in company B for men with 15-19 years' service and a slight excess in company A.

The analyses shown in table 4 showed some excesses in subgroups of the population that required further investigation. Table 5 gives the results of further analyses by age, job, and reason for leaving for men joining company B in or after 1960. Table 6 gives similar results for men from company B with 15-19 years' service. (The two excesses in company B were mutually exclusivethat is, none of those starting in 1960 had worked 15 years and all those with 15-19 years' service joined before 1960.)

In the cohort of those who joined in or after 1960 two thirds were aged under 55 at death, a pronounced excess. The observed deaths were more than those expected for all job groups except supervisors, although none of the excesses was statistically significant. There were also more observed deaths than expected in subgroups defined by when the death occurred (in service, after retirement, after leaving for other reasons), with an excess in those leaving fomother reasons. Of the 18 "other leavers," 15 had worked under five years. Of the 37 deaths in

Table 5 Observed deaths $(O)$, expected deaths $(E), O / E$, and $p$ values from ischaemic heart disease for men in company $B$ who started work in 1960 or after

\begin{tabular}{|c|c|c|c|c|}
\hline Subgroup & $O$ & $E$ & $O / E$ & $p$ \\
\hline No & 55 & 39.86 & $1 \cdot 38$ & 0.01 \\
\hline $\begin{array}{l}\text { Age: } \\
\quad<45 \\
45-54 \\
55-64 \\
65-74 \\
\geqslant 75\end{array}$ & $\begin{array}{r}15 \\
25 \\
8 \\
7 \\
-\end{array}$ & $\begin{array}{r}11 \cdot 71 \\
15 \cdot 37 \\
8.79 \\
3 \cdot 32 \\
0 \cdot 17\end{array}$ & $\begin{array}{l}1.28 \\
1.63 \\
0.91 \\
1.83 \\
-\end{array}$ & $\begin{array}{l}0.20 \\
0.01 \\
0.48 \\
0 \cdot 09 \\
0.84\end{array}$ \\
\hline $\begin{array}{l}\text { Job: } \\
\text { Operator } \\
\text { Driver } \\
\text { Craftsmen } \\
\text { General manual }\end{array}$ & $\begin{array}{r}15 \\
17 \\
3\end{array}$ & $\begin{array}{r}10 \cdot 92 \\
14 \cdot 17 \\
2 \cdot 34\end{array}$ & $\begin{array}{l}1 \cdot 37 \\
1 \cdot 20 \\
1 \cdot 28\end{array}$ & $\begin{array}{l}0.14 \\
0.26 \\
0.41\end{array}$ \\
\hline $\begin{array}{l}\text { worker } \\
\text { Security } \\
\text { Administrator } \\
\text { Supervisor }\end{array}$ & $\begin{array}{r}7 \\
4 \\
9 \\
-\end{array}$ & $\begin{array}{l}4 \cdot 25 \\
1.82 \\
5 \cdot 51 \\
0.85\end{array}$ & $\begin{array}{l}1 \cdot 65 \\
2 \cdot 20 \\
1 \cdot 63 \\
-\end{array}$ & $\begin{array}{l}0.14 \\
0.11 \\
0.11 \\
0.43\end{array}$ \\
\hline $\begin{array}{l}\text { Reason for leaving } \\
\text { Died } \\
\text { Retired } \\
\text { Other }\end{array}$ & $\begin{array}{r}31 \\
6 \\
18\end{array}$ & $\begin{array}{r}25 \cdot 80 \\
3.98 \\
10 \cdot 08\end{array}$ & $\begin{array}{l}1.20 \\
1.51 \\
1.79\end{array}$ & $\begin{array}{l}0.18 \\
0.21 \\
0.02\end{array}$ \\
\hline
\end{tabular}

Table 6 Observed deaths $(O)$, expected deaths $(E), O / E$, and $p$ values from ischaemic heart disease for men in company $B$ with 15-19 years' service

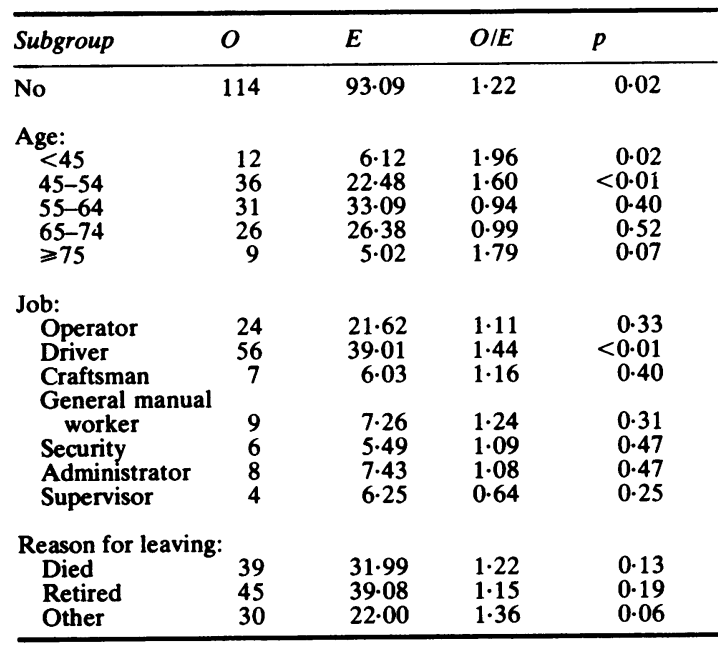

service or after retirement, 27 had worked five or more years.

There was also a pronounced excess in men aged under 55 at death for those with 15-19 years' service. There were more deaths observed than expected in all job groups except supervisors with a pronounced excess for drivers. Once again there were more deaths observed than expected for all categories defined by reason for leaving.

\section{DEATHS FROM MALIGNANT DISEASE}

Mortality from all neoplasms (table 7) was significantly lower than expected as was mortality from cancer of the lung. Deficits of observed deaths compared with those expected were found for cancer of the oesophagus, intestines, and bladder, and to a lesser extent for cancer of the stomach.

The lowered mortality overall for all neoplasms and cancer of the lung was found in particular in companies $\mathrm{B}$ and $\mathrm{C}$ and in several job groups. The ratio of observed to expected deaths tended to decrease with later cohort of entry for all neoplasms, especially in company $B$ where there was an excess for men joining in 1960 or after $(O=43, E=$ $32.78, p \leqslant 0.05)$. This was accounted for by an excess in this group from lung cancer $(O=19, E=$ $11.67, \mathrm{p}<0.05)$. There was also an excess from lung cancer for men in company $B$ with under five years' service $(O=34, E=24.37, p<0 \cdot 05)$. Of these 34 deaths, 25 had left for reasons other than death or retirement. Only three of these 25 died within five years of leaving and 15 died 10 years or more after leaving.

Mortality from all neoplasms of the lymphatic and 
Table 7 Observed and expected deaths, $O / E$, and $p$ values for all neoplasms and malignant causes with five or more observed deaths for workers employed in oil distribution centres in Britain from 1 January 1950 to 31 December 1975

\begin{tabular}{|c|c|c|c|c|}
\hline Cause (ICD order) & Observed deaths & Expected deaths & $O / E$ & $\boldsymbol{p}$ \\
\hline $\begin{array}{l}\text { All neoplasms } \\
\text { Cancer of mouth and tonsils } \\
\text { Cancer of pharynx } \\
\text { Cancer of oesophagus } \\
\text { Cancer of stomach } \\
\text { Cancer of intestines } \\
\text { Cancer of rectum } \\
\text { Cancer of liver and gall bladder } \\
\text { Cancer of pancreas } \\
\text { Cancer of lung and pleura } \\
\text { Cancer of skin (excluding scrotum) } \\
\text { Cancer of prostate } \\
\text { Cancer of testes } \\
\text { Cancer of urinary bladder } \\
\text { Cancer of kidneys and suprarenals } \\
\text { Cancer of brain and other parts of central }\end{array}$ & $\begin{array}{r}1002 \\
5 \\
7 \\
17 \\
123 \\
57 \\
57 \\
15 \\
39 \\
384 \\
5 \\
53 \\
6 \\
32 \\
23\end{array}$ & $\begin{array}{r}1156 \cdot 70 \\
4 \cdot 82 \\
6 \cdot 25 \\
28 \cdot 09 \\
144 \cdot 47 \\
71 \cdot 75 \\
53 \cdot 60 \\
20 \cdot 55 \\
46 \cdot 89 \\
482 \cdot 83 \\
8 \cdot 52 \\
48 \cdot 57 \\
5 \cdot 01 \\
42 \cdot 83 \\
19 \cdot 05\end{array}$ & $\begin{array}{l}0.87 \\
1.04 \\
1 \cdot 12 \\
0.61 \\
0.85 \\
0.79 \\
1.06 \\
0.73 \\
0.83 \\
0.80 \\
0.59 \\
1.09 \\
1.20 \\
0.75 \\
1.21\end{array}$ & $\begin{array}{c}<0.0001 \\
0.53 \\
0.43 \\
0.02 \\
0.08 \\
0.04 \\
0.34 \\
0.13 \\
0.14 \\
<0.0001 \\
0.15 \\
0.28 \\
0.39 \\
0.05 \\
0.21\end{array}$ \\
\hline $\begin{array}{l}\text { nervous system } \\
\text { Lymphosarcoma } \\
\text { Hodgkin's disease } \\
\text { Other neoplasms lymphoid tissue } \\
\text { Multiple myeloma } \\
\text { Leukaemia } \\
\text { Myelofibrosis }\end{array}$ & $\begin{array}{r}39 \\
7 \\
17 \\
6 \\
11 \\
28 \\
5\end{array}$ & $\begin{array}{r}36 \cdot 54 \\
8 \cdot 05 \\
12 \cdot 20 \\
3 \cdot 63 \\
9 \cdot 37 \\
26 \cdot 82 \\
1 \cdot 81\end{array}$ & $\begin{array}{l}1.07 \\
0.87 \\
1.39 \\
1.65 \\
1.17 \\
1.04 \\
2.76\end{array}$ & $\begin{array}{l}0.36 \\
0.45 \\
0.11 \\
0.16 \\
0.34 \\
0.44 \\
0.04\end{array}$ \\
\hline
\end{tabular}

haematopoietic tissue (ICD 8th revision 200-208) plus myelofibrosis (ICD 209) was slightly raised overall $(O=77, E=68.46, p=0.30)$ and in six of the eight individual neoplasms making up this disease group. With the exception of reticulum cell sarcoma, where there were only two deaths observed $(E=5.56, p=0.08)$, excesses of observed deaths were found for all these neoplasms in subgroups of the study population, although they are all based on small numbers of deaths. These excesses included: Hodgkin's disease in drivers overall $(O=9, E=$ $4.96, p=0.07)$; other neoplasms of the lymphoid tissue in company $\mathrm{C}(\mathrm{O}=5, \mathrm{E}=1.14, \mathrm{p}=0.01)$ and in operators overall $(\mathrm{O}=3, \mathrm{E}=0.74, \mathrm{p}=$ $0.04)$; multiple myeloma in operators from company $\mathrm{B}(\mathrm{O}=4, \mathrm{E}=1.14, \mathrm{p}<0.05)$; leukaemia in supervisors overall $(O=6, E=2 \cdot 80, p=0.07)$ and men starting before 1940 from company $\mathrm{B}(\mathrm{O}=15, \mathrm{E}=$ $7.76, \mathrm{p}<0.01)$; and myelofibrosis in company $\mathrm{B}(\mathrm{O}$ $=4, \mathrm{E}=1.05, \mathrm{p}<0.05)$. In an analysis of the deaths from leukaemia by histological type an excess from chronic lymphatic leukaemia was found in company $\mathrm{B}(\mathrm{O}=8, \mathrm{E}=3.43, \mathrm{p}<0.05)$ (comparison rates by histological type for the only available quinquennium 1971-5 were used for all calendar period groups). The observed deaths from acute myeloid leukaemia (9), which has been particularly associated with exposure to benzene, approximately equalled those expected (9.91).

\section{Discussion}

The patterns of mortality were not consistent in the three companies studied but the data sources and the composition of the population were rather different. The information for company $\mathrm{C}$ was taken mainly from pension records, and records for men leaving for reasons other than death or retirement were mostly unavailable. An appreciable number of men from company $C$ were therefore not included in the study. These leavers, however, were likely to have been younger and with shorter service than men who had retired or died in service. They would be likely to contribute comparatively fewer deaths to the study than the other two groups of leavers. ${ }^{26} \mathrm{It}$ is also not clear whether all men from company $\mathrm{C}$ who died in service were eligible for a pension and were thus included in the study. For example, in company B the deaths in service constituted about a third of the total of all deaths in service and after retirement compared with only a quarter in company $\mathbf{C}$.

In company $A$ a larger proportion of the men left for reasons other than death or retirement than in the other two companies. (These men were generally young when they left and had short service.) This may be because company A took over several small companies that had had a relatively quick turnover of employees. These differences may contribute to some extent to the non-comparability of the results between the companies.

Some of the limitations of this type of study and the problems inherent in interpreting the results have been discussed in our previous report on the refinery workers. ${ }^{1}$ These include inaccuracy in diagnosis, classification, and coding of the causes of death, and omission of information from the death details; the identification of the true "occupational" 
hazard when many comparisons of observed and expected deaths are made; small numbers in the study; and short period of follow up. The detailed examination of the data has been used to describe the patterns of mortality and to search for consistency across the subgroups of the population.

Other factors that may influence variations in mortality include $(a)$ use of inappropriate rates in calculating the expected deaths, $(b)$ varying patterns of diagnosis and certification in different regions, $(c)$ variation in the observed deaths due to chance, $(d)$ external (non-occupational) factors such as the lifestyle of those in the study population influencing the mortality patterns, and (e) an occupational environmental factor influencing the mortality risk.

Overall the mortality of the study population is much lower than that of the standard population with which it was compared. This result may be due to the comparison of an industrially employed cohort with a standard population that includes those in unstable employment and the chronically ill and disabled. This reduction in comparison with deaths expected from national mortality rates is the usual finding in such studies-for example, the refinery and London Transport studies.

This low overall mortality usually extends to the broad causes of death responsible for large numbers of deaths, particularly the non-malignant causes. Table 8 gives the ratios of observed over expected deaths for all causes of death and three numerically large causes of death separately for the distribution centre, refinery, and London Transport studies. These ratios are based on large numbers of deaths and chance fluctuations may be excluded. All the ratios are low except that for ischaemic heart disease in the distribution workers. This result seems out of line on examination of both the data from these three studies and also in relation to published comparative studies. In addition, ratios for lung cancer in both the refinery study and distribution centre study are low $(0.78$ and 0.80 respectively). It was suggested that the refinery results might be, in part, due to reduction in smoking by the men in comparison with the general population-smoking is one of

Table 8 Comparison of the ratio of observed deaths over expected deaths for main causes of death in the three studies carried out

\begin{tabular}{llll}
\hline & Refineries & $\begin{array}{l}\text { Distribution } \\
\text { centres }\end{array}$ & $\begin{array}{l}\text { London } \\
\text { Transport } \\
\text { Executive }\end{array}$ \\
\hline $\begin{array}{l}\text { All causes } \\
\begin{array}{l}\text { Cerebrovascular } \\
\text { disease }\end{array}\end{array}$ & 0.84 & 0.85 & 0.84 \\
$\begin{array}{l}\text { Ischaemic } \\
\text { heart disease }\end{array}$ & 0.90 & 0.87 & 0.78 \\
\begin{tabular}{l} 
Bronchitis \\
\hline
\end{tabular} & 0.60 & 0.99 & 0.74 \\
\hline
\end{tabular}

the known aetiological factors for the three causes of death shown in table 8.

These points suggest that the result for the distribution centre for ischaemic heart disease is unexpected. The overall mortality from this cause is not higher than in the general population but is not reduced as one would have expected from the other results. This prompted a particular scrutiny of subgroups of the distribution centre workforce to check for any evidence that mortality was increased over the ratio of 0.90 , the typical finding. As described above several excesses of observed deaths were found in subgroups of the population, particularly in company B.

In the refinery study it has been shown that low mortality overall and from numerically large nonmalignant causes is particularly pronounced for deaths in service but that the ratio of observed over expected deaths tends to approach or exceed unity-that is, the healthy worker effect disappears-for both deaths after retirement and deaths after leaving for other reasons. ${ }^{26}$ The disappearance of the healthy worker effect for the latter group of relatively young, short service men suggested that they differed from the stable workforce both in employment history and in aspects (albeit unknown) of their lifestyle. In the distribution centre study the same pattern was generally found, including mortality from ischaemic heart disease. The analyses in tables 5 and 6 also show this higher mortality for the "other leavers." Unlike the other large disease groups, however, there is no significant deficit from ischaemic heart disease for deaths in service from company $B$ and the observed deaths (227) approximately equal those expected $(231 \cdot 64)$. This again is an unexpected result.

The healthy worker effect consists of two parts, the selection effect and the survival effect. ${ }^{27}$ It has been suggested that many of the distribution centre study population started work before the introduction of pre-employment medical examinations and before heavy goods vehicles licenses were required. It has been pointed out, however, that many men were previously employees of the Petroleum Board which would have required some overall standard of health. There is no suggestion that the procedure of selection of a healthy workforce is likely to be different for ischaemic heart disease than for other diseases, such as hypertensive disease or respiratory disease, where a healthy worker effect was observed. The survival effect therefore may differ in this study population, particularly for company B for ischaemic heart disease, perhaps due to a difference in lifestyle or to an occupational risk. The data are not sufficiently detailed in this particular study, however, to follow this issue further. 
The expected deaths were not adjusted to take account of regional or social class variation in mortality. As the centres were scattered throughout Britain it was thought that any regional differences in mortality balanced out overall. There were three excesses found in non-malignant disease groups for general manual workers-cerebrovascular disease, other diseases of the circulatory system, asthma, and an excess from bronchitis for security men. These, however, were not greater than expected compared with all men of the appropriate social class. The standardised mortality ratios for ischaemic heart disease increased from 88 in social class $I$ to 111 in social class $V .{ }^{28}$ The conclusions drawn from the results described above, however, would not differ if adjustments were made using these figures.

Most of the other excesses from non-malignant disease groups occurred in isolated subgroups of the population and were mainly based on small numbers of deaths. There is no evidence that any of these were occupational in origin.

Mortality from all neoplasms was much lower than expected, especially for drivers, craftsmen, administrators, and supervisors. Mortality from lung cancer was also much lower overall and in these job groups. Mortality from all neoplasms tended to increase with later cohort of entry overall, especially in company $B$ with an excess for those men joining this company in 1960 or after. This was accounted for by an excess in lung cancer for men from company B with less than five years' service. An absence of heavy smokers, perhaps due to the restrictions of smoking demanded by the nature of the work, might account for the general low mortality from lung cancer. Those who left with under five years' service were usually young and presumably went to other occupations. Most died several years after leaving the oil company. Possibly the smoking habits of these men differed from the more stable workforce, but there are no reliable data with which to investigate this.

Unlike the refinery study ${ }^{1}$ mortality from cancer of the gastrointestinal tract was not increased and the overall mortality from this was significantly lower than expected. There were conflicting results for drivers for stomach cancer with an excess in company $\mathrm{C}$ and a deficit in company $\mathrm{B}$. There was also no raised mortality from either melanoma or cancer of the nasal cavities and sinus, both of which showed excesses in the refinery study. There was no excess of observed deaths from epithelioma and no deaths at all from scrotal cancer, both of which have been shown in previous studies to be associated with contact with mineral oil. ${ }^{10}$

Other work indicated the need to look carefully at the mortality from leukaemia and the other neo- plasms of the lymphatic and haematopoietic tissue. ${ }^{2111329}$ In the distribution centre study there were slightly more deaths observed than expected from all neoplasms of the lymphatic and haematopoietic tissue. For all men in the study none of the seven specific forms of neoplasm examined shows a significant increase. There were slightly more deaths observed than expected overall for leukaemia and approximately the same number of deaths observed as expected from acute myeloid leukaemia, which has been particularly associated with exposure to benzene. There was, however, an excess of deaths from chronic lymphatic leukaemia in men from one company with long service. There were excesses in subgroups of the study population in most of the other diseases making up diseases of the lymphatic and haematopoietic tissue. There was also an excess from myelofibrosis which is an associated disease. These diseases are rare and the numbers of deaths, even with such a large study population as the distribution centre study, are likely to be small. The identification of the causative factors of these diseases is thus made even more difficult.

A large number of distribution centres were included in this study. The numbers of men and numbers of deaths from each centre were thus rather small for a formal analysis. Nevertheless, there was no indication from an informal examination of the deaths by distribution centre that any individual centre was particularly concerned. Inspection of the material did not show any clustering of results in neighbouring distribution centres within the same region.

A comparison of the results found in this study with published national occupational mortality data is not really feasible as the classifications used by the Registrar General, such as welder, boilermaker, engineer, do not distinguish the industry in which such men work. As in the refinery study process workers are included in the classification "chemical production process workers not elsewhere classified." Death rates for men aged 15-64 in this group were slightly higher than for all men of this age group ${ }^{28}$ but the difference disappeared when social class standardisation was carried out. An excess of stomach cancer was also found, but was partially removed by social class standardisation.

Drivers are included in the classification "drivers of road goods vehicles." The SMR for men aged 15-64 in this group was 111 but fell to 106 when social class was taken into account. Excesses were found for motor vehicle accidents, cancer of the stomach, and lung cancer. The excess from lung cancer remained significant when social class was taken into account and was associated with an excess from bronchitis, emphysema, and asthma. It was 
suggested in the Occupational Mortality Decennial Supplement that this was the "result of social habits such as smoking which were probably adopted more often or to a greater degree by men in this classification than by other men in the same social class." In the present study deaths from cancer of the lung, bronchitis, emphysema, and asthma are much lower than expected overall and for drivers. This suggests that smoking may be lower in the study population than in men of the same social class or occupational unit. By contrast, ischaemic heart disease, which is also related to smoking, shows no lowered mortality.

\section{Conclusions}

The analyses of the distribution centre data suggest that consideration might be given to further study of both ischaemic heart disease and diseases of the lymphatic and haematopoietic tissue. The information collected, however, was limited in respect of both the details collected on each man and the length of follow up. Various methods of follow up that could be considered when assessing the results of this study include carrying out a prevalence survey to investigate ischaemic heart disease using a questionnaire to obtain details of symptoms such as angina and taking physical measurements-for example, using an ECG; carrying out case-control studies using internally matched controls and examining information about job history and other environmental factors-this would be appropriate for investigating both prevalent cases of heart disease and deaths from ischaemic heart disease and neoplasms of the lymphatic and haematopoietic tissue; extending the duration of follow up of the study to establish whether the mortality patterns found in 1950-75 continue, although a minimum of a further 10 years' follow up would be required; and investigating whether the collection of environmental measures and detailed job history information could provide more precise indicators of exposure to relate to the incidence of the various diseases.

The clerical side of this study was handled by Mrs Carol Fair and Ms Deborah Cummings. We have benefited from the help of many colleagues, especially Dr Joan Davies, Dr David Jones, and Mrs Doreen Folkes.

The basic information was extracted from records at the head and regional offices of the companies concerned. We are grateful to OPCS, DHSS, and the Registrar General for Scotland for tracing the leavers. The study benefited from the help and advice of a working party of the Institute of Petroleum chaired by Dr W B L Leese. The main fund- ing was a grant from the Institute of Petroleum. The Cancer Research Campaign support of the division of epidemiology is also gratefully acknowledged.

Requests for reprints to: Dr L Rushton, Thames Polytechnic, School of Mathematics, Statistics and Computing, Wellington Street, London SE18 6PF.

\section{References}

' Rushton L, Alderson MR. An epidemiological survey of eight oil refineries in Britain. Br J Ind Med 1981;38:225-34.

${ }^{2}$ Rushton L, Alderson MR. A case-control study to investigate the association between exposure to benzene and deaths from leukaemia in oil refinery workers. Br J Cancer 1981;43:77-84.

${ }^{3}$ Rushton L, Alderson MR. An epidemiological survey of maintenance workers in London Transport Executive bus garages and Chiswick Works. (Final report.) London: Institute of Petroleum, 1982.

4 Twort CC, Twort JM. The carcinogenic potency of mineral oils. Journal of Industrial Hygiene 1931:13:204-26.

soodhouse DL, Irwin JO. The carcinogenic activity of some petroleum factions and extracts. $J$ Hyg 1950;48:121-34.

- Henry SA. Cancer of the scrotum in relation to occupation. London: Oxford University Press, 1946.

${ }^{7}$ Cruickshank CND, Squire JR. Skin cancer in the engineering industry from the use of mineral oil. $B r J$ Ind Med 1950;7:1-11.

- Baylor $\mathbf{C H}$, Weaver NK. A health survey of petroleum asphalt workers. Arch Environ Health 1968;17:210-4.

${ }^{2}$ Hendricks NV, Berry CM, Lione JG, Thorpe JJ. Cancer of the scrotum in wax pressmen. Arch Environ Health 1959;19:524-9.

${ }^{10}$ Wade L. Observations on skin cancer among refinery workers. Arch Environ Health 1963:6:730-5.

"Tabershaw IR. A mortality study of petroleum refinery workers. New York: American Petroleum Institute, 1974. (API project OH-1 No 129.)

12 Theriault G, Goulet L. A mortality study of oil refinery workers. JOM 1979;21:367-80.

13 Thomas TL, Decoufle P, Moure-Eraso R. Mortality among workers employed in petroleum refining and petrochemical plants. JOM 1980;22:97-103.

14 Hanis NM, Stavraky KM, Fowler JL. Cancer mortality in oil refinery workers. JOM 1979;21:167-74.

15 Hearey CD, Ury H, Siegelamb A, et al. Lack of association between cancer incidence and residence near petro-chemical industry in the San Francisco Bay area. J Natl Cancer Inst 1980;64:1295-9.

${ }^{16}$ Gottlieb MS. Lung cancer and the petroleum industry in Louisiana. JOM 1980;22:384-8.

17 Parkinson GS. Benzene in motor gasoline-an investigation into possible health hazards in and around filling stations and in normal transport operations. Ann Occup Hyg 1971;14:155-7.

1s Sherwood RJ. Evaluation of exposure to benzene vapour during the loading of petrol. Br J Ind Med 1972;29:65-9.

${ }^{19}$ Irving J, Grumbles TG. Benzene exposure during gasoline loading at bulk marketing terminals. Am Ind Hyg Assoc J 1979;40:468-73.

${ }^{20}$ McDermott HJ, Vos GA. Service station attendants' exposure to benzene and gasoline vapors. Am Ind Hyg Assoc J 1979;40:315-21.

${ }^{21}$ Burklin EC. Background information on hydrocarbon emissions from marine terminal operations. Vol I. Washington: Environmental Protection Agency, 1976.

${ }^{22}$ Phillips CF, Jones RK. Gasoline vapor exposures during bulk handling operations. Am Ind Hyg Assoc J 1978;39:119-28. 
${ }^{23}$ World Health Organisation. Manual of international classification of diseases, injuries and causes of death. Vols 1, 2. Geneva: WHO, 1948, 1957, 1967.

${ }^{24}$ Hill ID. Computing man years at risk. Br J Prev Soc Med 1973;26:132-4.

${ }^{25}$ Case RAM, Coghill C, Davies JM, et al. Serial mortality tables, neoplastic diseases. Vol 1. England and Wales 1911-70. London: Institute of Cancer Research, 1976.

${ }^{26}$ Rushton L. An investigation of some methods for occupational mortality studies based on a study of eight British oil refin.ries. London: London University, 1981. (PhD thesis.)

${ }^{27}$ Fox AJ, Collier PF. Low mortality rates in industrial cohort studies due to selection for work and survival in the industry. Br J Prev Soc Med 1976;30:225-30.

${ }^{28}$ Office of Population Censuses and Surveys. Occupational Mortality 1970-72. Series DS No 1. London: HMSO, 1978.

${ }^{29}$ Goldstein BD. Haematotoxicity in humans. J Toxicol Environ Health 1977; suppl 2:69-106.

\section{Vancouver style}

All manuscripts submitted to the $B r J$ Ind Med should conform to the uniform requirements for manuscripts submitted to biomedical journals (known as the Vancouver style).

The $B r J$ Ind Med, together with many other international biomedical journals, has agreed to accept articles prepared in accordance with the Vancouver style. The style (described in full in Br Med J, 24 February 1979, p 532) is intended to standardise requirements for authors.

References should be numbered consecutively in the order in which they are first mentioned in the text by Arabic numerals above the line on each occasion the reference is cited (Manson ${ }^{1}$ confirmed other reports ${ }^{2-5} \ldots$ ). In future references to papers submitted to the $B r J$ Ind Med should include: the names of all authors if there are six or less or, if therc are more, the first three followed by et al; the title of journal articles or book chapters; the titles of journals abbreviated according to the style of Index Medicus; and the first and final page numbers of the article or chapter.

Examples of common forms of references are:

1 International Steering Committee of Medical Editors. Uniform requirements for manuscripts submitted to biomedical journals. Br Med J 1979;1 :532-5.

2 Soter NA, Wasserman SI, Austen KF. Cold urticaria: release into the circulation of histamine and eosinophil chemotactic factor of anaphylaxis during cold challenge. $N$ Engl J Med 1976;294:687-90.

${ }^{3}$ Weinstein L, Swartz MN. Pathogenic properties of invading micro-organisms. In: Sodeman WA Jr, Sodeman WA, eds. Pathologic physiology: mechanisms of disease. Philadelphia: W B Saunders, 1974:457-72. 